\title{
PEMBERDAYAAN EKONOMI MASYARAKAT MISKIN DI YAYASAN PERJUANGAN WAHIDIYAH
}

\author{
Azis Muslim \\ Universitas Islam Negeri Sunan Kalijaga Yogyakarta \\ muslimtenan@gmail.com
}

\begin{abstract}
Poverty is a miserable condition. Efforts to reduce poverty have been done by the government, but the results are not satisfied. Therefore, we need the involvement of otherparties, such as religious institutions. This study aims to assess the involvement of Wabidiyah Struggle Foundation in tackling the problem of poverty through economic empowerment. The study focuses on the concept, implementation, and results of economic empowerment. Research uses qualitative method and collect data through observation, indepth interview, and documentation. Research found that Wahidiyah builds micro finance organizations as a central concept in economic empowerment. Their function is not only to increase financial capital, but also create solidarity among members. Strong solidarity among members was utilized to assist strengthening economic empowerment among themselves. This increase Wabidiyah member's income significantly.
\end{abstract}

Keywords: Poverty, Economic Empowerment, Wahidiyah.

\begin{abstract}
Abstrak
Kemiskinan merupakan kondisi yang menyedihkan.Upaya untuk mengentaskan kemiskinan telab banyak dilakukan oleb pemerintah, namun hasilnya belum memuaskan. Karena itu, dibutubkan keterlibatan pihak lain, seperti lembaga keagamaan. Penelitian ini bertujuan mengkaji keterlibatan Yayasan Perjuangan Wabidiyah dalam menanggulangi masalab kemiskinan melalui usaha pemberdayaan ekonomi. Penelitian difokuskan pada konsep, implementasi, dan hasil pemberdayaan ekonomi. Penelitian dilakukan secara kualitatif dengan metode pengumpulan data melalui observasi, wawancara, dan dokumentasi. Berdasarkan hasil penelitian ditemukan bahwa Wabidiyah menjadikan koperasi sebagai konsep pokok dalam pemberdayaan ekonomi. Koperasi selain dijadikan sarana pembangunan modal finansial, juga dijadikan wadah pembangunan solidaritas antar anggota. Solidaritas anggota yang kuat dimanfaatkan untuk saling membantu dalam pemberdayaan ekonomi sesama. Langkah ini ternyata membuabkan hasil nyata, yaitu meningkatnya pendapatan jamaah Wabidiyah.
\end{abstract}

Kata kunci: Kemiskinan, Pemberdayaan Ekonomi, Wahidiyah

Permalink/DOI: http://dx.doi.org/10.18326/infsl3.v10i2.335-358 


\section{Pendahuluan}

Dakwah bil-hāl bukan wacana baru dalam literatur Islam. Namun istilah dakwah bil-hāl yang muncul di awal 1980-an ini menjadi perbincangan yang hangat kembali setelah Dahlan Iskan sebagai menteri BUMN menyampaikan pidato mengenaipentingnya dakwah bil-hāl untuk mewujudkan masyarakat Islam yang maju dan mandiri di bidang ekonomi pada upacara penganugerahan Doktor Honoris Causa di Institut Agama Islam Negeri Walisongo Semarang (Jawa Pos, 9 Juli 2013). Model dakwah ini dipandang tepat untuk melakukan pemberdayaan masyarakat karena langsung menyentuh jantung masalah yang selama ini banyak dirasakan oleh masyarakat, yaitu kemiskinan dan kesenjangan ekonomi.

Jauh sebelum Dahlan Iskan menyampaikan pidato tersebut, Maftuh Basyuni selaku Menteri Agama mencanangkan pos pemberdayaan keluarga (Posdaya) berbasis masjid pada tanggal 11 Februari 2007 di Masjid At-Tawazun Pemalang Jawa Tengah. Menteri mengingatkan cara memakmurkan masjid adalah "memanfaatkan masjid tidak hanya dijadikan sebagai kegiatan ibadah saja, melainkan dilengkapi dengan berbagai kegiatan pemberdayaan masyarakat" (Gemari, 2007: 58) khususnya pemberdayaan di bidang ekonomi.

Benang merah dari pemikiran kedua tokoh di atas adalah pentingnya keterlibatan lembaga keagamaan dalam mengatasi permasalahan umat, khususnya masalah kemiskinan dan kesenjangan ekonomi dengan menggunakan pendekatan dan metode yang tepat. (Muslim 2014: 2) menyatakan bahwa keterlibatan lembaga keagamaan dalam penanganan masalah kemiskinan dipastikan mampu mengurangi angka kemiskinan.Sejarah perkembangan Islam di Indonesia menunjukkan bahwa terdapat hubungan yang cukup erat antara dakwah Islam dan pemberdayaan ekonomi. Islam masuk di Nusantara melalui para sufi (Azra, 2004) dan pedagang yang aktif melakukan dakwah dan perdagangan serta lembaga keagamaan dijadikan sebagai pusat pendidikan (Abdullah, 1994 dan Sobary, 1995). Ini artinya dakwah yang dilakukan oleh lembaga yang memiliki kemampuan memilih metode yang tepat dapat mengatasi permasalahan yang menghimpit mad'unya. 
Dakwah dalam kerangka penyelesaian persoalan masyarakat tidak cukup dilakukan secara verbal (ceramah) saja, tetapi juga perlu dilakukan dengan tindakan. Dakwah tidak hanya sebatas penyampaian (tabligh), penyadaran (taușiyah), pembimbingan (tarshid), tetapi juga pemberdayaan (tathwir). Bagi masyarakat Indonesia yang jumlah angka kemiskinannya masih relatif tinggi, dakwah semestinya tidak hanya dilakukan untuk menyampaikan pesan kebaikan saja, tetapi juga untuk menyelesaikan persoalan masyarakat melalui kegiatan-kegiatan sosial, ekonomi bahkan politik sekalipun, sehingga masyarakat tidak hanya meningkat kualitas keagamaannya, tetapi juga terangkat status sosial ekonominya. Karena itu, partisipasi lembaga keagamaan dalam pernyelesaian persoalan kemiskinan dan kesenjangan ekonomi jelas sangat diperlukan. Sebagaimana dijelaskan oleh Oepen dan Karcher (1988) bahwa lembaga keagamaan memiliki empat (4) peran, yaitu membebaskan dan menyadarkan masyarakat dari kondisi kehidupan sosial yang menghimpit seperti kemiskinan, menggerakkan partisipasi dan etos swadaya masyarakat dengan memposisikan dirinya (lembaga) sebagai fasilitator, mendidik ketrampilan dan menciptakan pengetahuan, dan mempelopori caracara memecahkan persoalan kehidupan kemasyarakatan.

Di antara lembaga yang telah melakukan peran di atas adalah Yayasan Perjuangan Wahidiyah. Yayasan yang sering disebut dengan Wahidiyah ini melakukan dakwah tidak hanya sebatas menyampaikan pesan kebaikan (tabligh) dan penyadaran (tausyiah), tetapi juga melakukan pemberdayaan (tathwir) khususnya di bidang ekonomi. Yayasan yang berpusat di Bandar Lor Mojoroto Kota Kediri Jawa Timur ini memiliki pengikutyang besar dan tersebar di seluruh pelosok Nusantara. Hal ini tentu menarik untuk dikaji karena, pertama, kebanyakan lembaga keagamaan yang memiliki pengikut besar seperti Nahdlatul Ulama, Muhammadiyah, Lembaga Dakwah Islam Indonesia, Majlis Tafsir Al-Qur'an dan lainnya kurang peduli pada kondisi ekonomi jamaahnya, sebaliknya Wahidiyah sangat pedulidan penuh perhatian terhadap kondisi ekonomi jamaahnya. Kedua, minimnya kajian yang membahas permasalahan ini.Fauroni (2011), Muttaqin (2011), dan Chotimah (2014), misalnya, membahas tentang peran lembaga keagamaan dalam pemberdayaan ekonomi 
santri yang tinggal di pesantren. Sementara, penelitian ini mengkaji tentang peran lembaga keagamaan dalam pemberdayaan ekonomi pada masyarakat yang tinggal di luar pesantren.

Penelitian ini difokuskan pada konsep, implementasi, dan hasil pemberdayaan ekonomi yang dilakukan oleh Wahidiyah. Penelitian ini menggunakan pendekatan kualitatif fenomenologis dengan metode pengumpulan data melalui observasi, wawancara, dan dokumentasi. Keabsahan data dilakukan dengan pengamatan secara mendalam dan triangulasi, sedangkan analisis data dilakukan secara interaktif.

\section{Wahidiyah dan Perannya dalam Penanggulangan Kemiskinan}

Nama Wahidiyah diambil dari sebutan Sholawat Wahidiyah, yaitu sebuah sholawat yang digunakan sebagai amalan untuk mendekatkan diri kepada Allah swt. Sholawat ini ditulis oleh KH. Abdoel Madjid Ma'roef seorang pengasuh pesantren alMunadhdharah atau yang lebih dikenal dengan pesantren Kedunglo. Sholawat ini pertama kali dideklarasikan pada bulan Muharram tahun 1963 di Musholla KH. Abdul Jalil di Jamsaren Kediri. Kemudian setahun setelah deklarasi, setiap bulan Muharram selalu diadakan peringatan ulang tahun kelahiran sholawat tersebut. Ulang tahun Sholawat Wahidiyah dilaksanakan di pesantren al-Munadhdharah di Kedunglo dengan menggelar mujahadah kubro yang dihadiri oleh para pengamalnya dari berbagai wilayah.

Sepeninggal penulis Sholawat Wahidiyah, KH. Abdoel Madjid Ma'roef, Wahidiyah mengalami dinamika kesejarahan di kalangan internal. Di antaranya adalah munculnnya tiga aliran Wahidiyah, yakni Penyiar Sholawat Wahidiyah (PSW), Pimpinan Umum Perjuangan Wahidiyah (PUPW), dan Jamaah Perjuangan Wahidiyah Miladiyah (JPWM). PSW merupakan organisasi yang dibentuk oleh penulis Sholawat Wahidiyah sendiri semasa masih hidup dan beliau juga memimpin langsung perjuangan dan penyiaran Wahidiyah. Pada masa tersebut, PSW berpusat di Kedunglo Kediri dan sempat didaftarkan sebagai organisasi kemasyarakatan yang berbadan hukum di Indonesia. Pada perkembangannya, pusat organisasi tersebut pindah ke Rejoagung, Ngoro, Jombang, tepatnya di Pondok Pesantren at-Tahdzib. Perpindahan pusat organisasi ini terjadi 
setelah munculnya organisasi baru, yaitu PUPW yang diwadahi oleh Yayasan Perjuangan Wahidiyah dan Pesantren al-Munadhdharah di Kedunglo, Kediri.

Yayasan Perjuangan Wahidiyah ini berpusat di Kedunglo, Kediri dan dipimpin oleh KH. Abdul Latief Madjid, salah seorang putra penyusun Sholawat Wahidiyah. Sebagaimana PSW, Yayasan Perjuangan Wahidiyah ini juga mempunyai masa pengikut yang tidak sedikit. Hal ini secara sosial dapat dipahami karena adanya dua faktor penting, yaitu faktor silsilah (genetik) tokohnya sebagai putra penyusun Sholawat Wahidiyah, dan faktor teritorial sebagai tempat kelahiran dan pusat awal perkembangan Wahidiyah.

Munculnya konflik yang sering ditimbulkan oleh PSW dan PUPW memaksa KH. Abdul Hamid mendirikan organisasi baru, yaitu Jamaah Perjuangan Wahidiyah Miladiyah (JPWM). Organisasi yang didirikan pada tahun 1994 ini dipimpin langsung oleh KH. Abdul Hamid, salah seorang putra penyusun Sholawat Wahidiyah, dan berpusat di Kedunglo, Kediri. Organisasi ini muncul dengan ide dasar sebagai penengah antara PSW dan PUPW. Bahkan pada masamasa awal kelahirannya, organisasi ini merelakan diri dijadikan kritik untuk menetralisir ketidakharmonisan antara PSW dan PUPW. JPWM memiliki pengikut tersendiri, meskipun jumlahnya tidak sebanyak masa pengikut PSW dan juga PUPW. Alasan masa pengikut JPWM sama dengan alasan masa pengikut PUPW, yaitu karena faktor genetik dan teritorial.

Dalam perkembangannya, PUPW mempunyai pengikut paling banyak dibanding PSW dan JPWM. Hal ini terbukti saat PUPW mengadakan acara mujahadah kubro pada tahun 1993 di Pondok Pesantren Kedunglo, Kediri. Massa yang hadir pada acara itu mencapai sekitar 20.000 (dua puluh ribu) orang. Pada saat yang sama, Mujahadah Kubro I yang diadakan PSW di Pondok Pesantren at-Tahdzib di Rejoagung Ngoro Jombang hanya dihadiri oleh sekitar 300 (tiga ratus) orang. Pada Mujahadah Kubro II, massa yang hadir meningkat sekitar 1.200 (seribu dua ratus) orang. Namun pada Mujahadah Kubro berikutnya kondisinya semakin menurun. Sementara, mujahadah Kubro I dan II yang diadakan oleh PUPW terus menunjukkan peningkatan pesertanya. 
Banyaknya pengikut PUPW/Yayasan Perjuangan Wahidiyah yang berasal dari kalangan masyarakat miskin dan sulitnya mengakses modal usaha mendorong KH. Abdul Latief Madjid membangun sebuah lembaga keuangan, yaitu Koperasi Wahidiyah. Dengan adanya koperasi, beliau berharap bahwa Wahidiyah tidak hanya dapat melakukan pemberdayaan ruhani sebagaimana yang sering dilakukan lewat mujahadah, tetapi juga dapat melakukan pemberdayaan ekonomi khususnya bagi para pengikutnya. Karena itu, sejak mendeklarasikan berdirinya Koperasi Wahidiyah pada tahun 1999 beliau selalu mendengungkan pentingnya koperasi bagi pengamal Wahidiyah. Usaha keras KH. Abdul Latief Madjid itu tampak membuahkan hasil. Hal ini terbukti dengan munculnya cabang Koperasi Wahidiyah yang berjumlah lebih dari 901 buah di seluruh Nusantara.

Koperasi Wahidiyah yang dijadikan sarana dakwah bil-hā $l$ bagi Yayasan Perjuangan Wahidiyah memiliki tujuan luhur yaitu mengurangi angka kemiskinan dengan membangun perekonomian masyarakat miskin. Untuk mewujudkan tujuan itu, koperasi Wahidiyah membangun program utama yaitu menyediakan pinjaman modal usaha, membantu memasarkan produk usaha, dan memberikan pelatihan ketrampilan usaha.

\section{Karakteristik Masyarakat Miskin di Wabidiyah}

Masyarakat/jamaah Wahidiyah menurut Kyai Abdul Latief Madjid dan Kyai Zainuddin mayoritas berasal dari kalangan masyarakat miskin. Kemiskinan mereka dipengaruhi oleh beberapa hal, di antaranya adalah keterbatasan akses modal usaha. Seperti dirasakan oleh Tatik Mariyah pedagang nasi pecel yang tinggal di Kedunglo Mojoroto Kediri. Beliau menceritakan pengalamannya bahwa usahanya tidak dapat berkembang dikarenakan keterbatasan akses modal usaha. Upayanya mencari pinjaman modal untuk mengembangkan usaha tidak pernah berhasil karena tidak ada jaminan atau agunan yang dimiliki.

Faktor lain yang menjadi penyebab kemiskinan jamaah Wahidiyah adalah kurangnya ketrampilan di bidang pemasaran. Iwan sebagai seorang peternak ulat kandang, misalnya menuturkan bahwa dirinya tidak menjual sendiri hasil ternaknya ke pasar 
karena merasa canggung. Beliau menggantungkan pemasaran hasil usahanya pada orang lain atau koperasi.

Sulitnya mencari ijin usaha, juga menjadi faktor penyebab kemiskinan bagi jamaah Wahidiyah. Sutrisno sebagai pengrajin bakpia apel, misalnya, menuturkan sulitnya mencari ijin usaha, meskipun hanya ijin P-IRT (Produksi Industri Rumah Tangga) dari Dinas Kesehatan setempat. Beliau menuturkan bahwa sampai saat ini ijin usahanya belum ada, sehingga produk usahanya tidak dapat dijual lewat toko-toko besar.

Selain faktor sulitnya mencari ijin usaha, faktor kecilnya pendapatan juga mempengaruhi kemiskinan bagi jamaah Wahidiyah. Tarmuji sebagai pedagang bakso keliling. Persaingan usaha juga mempengaruhi faktor penyebab kemiskinan pada jamaah Wahidiyah. Imam Masrukin, misalnya menjelaskan bahwa besar kecilnya pendapatan yang diperoleh per hari dipengaruhi oleh banyaknya usaha yang sejenis. Faktor lain yang menjadi penyebab kemiskinan bagi jamaah Wahidiyah adalah keterbatasan tempat usaha yang strategis. Supomo dan Irvan Zainuri sebagai pedagang kaki lima, misalnya, menuturkan pernah digusur karena tempat usahanya akan dibangun terminal baru.

\section{Konsep Penanggulangan Kemiskinan di Wahidiyah}

Wahidiyah membangun ekonomi jamaahnya melalui sistem koperasi. Sistem ini dipandang paling memungkinkan mengingat mayoritas jamaah Wahidiyah berasal dari kalangan masyarakat ekonomi kelas bawah.

Sistem ini jamaah Wahidiyah diharapkan mampu membangun modal finansial yang pada gilirannya nanti diharapkan juga mampu bersaing dengan pemodal-pemodal besar lainnya untuk membangun perekonomian jamaahnya. Selain itu, alasan Wahidiyah memilih koperasi sebagai lembaga keuangannya adalah menerapkan salah satu dari lima ajaran pokoknya, yaitu taqdimul-ahamm fal-ahamm tsummal-anfa' fal-anfa' (mendahulukan yang penting, kemudian yang paling besar manfaatnya). Lima (5) ajaran pokok Wahidiyah adalah lillāb-billāh, lir-rasulbir-rasul, lil-ghoutsbil-ghouts, yukti kulla dzi haqqin haqqoh, dan taqdimul-ahamm fal-ahamm 
tsummal-anfa' fal-anfa'. Membangun koperasi adalah sesuatu yang penting mengingat mayoritas jamaah Wahidiyah berasal dari kalangan masyarakat miskin yang secara material selalu kekurangan. Sementara, koperasi mampu memberikan manfaat yang besar bagi anggotanya, khususnya dalam membangun permodalan. Alasan ini diperkuat juga dengan kaidah ushul fiqih yang menyatakan bahwa dar'ul-mafasid muqaddamun ala jalbil-mashalih (mencegah kerusakan didahulukan dari pada menarik kemaslahatan), dan doktrin akhlaq yang menyatakan bahwa mura'atul-adabi muqaddamun 'ala imtisalil-awamiri (memelihara adab didahulukan dari pada menjalankan berbagai macam perintah).

Koperasi Wahidiyah menerapkan prinsip dari, oleh dan untuk jamaah. Artinya koperasi Wahidiyah modal dasarnya harus berasal dari jamaah. Modal koperasi yang sudah terkumpul dipergunakan oleh jamaah untuk kepentingan membangun ekonomi jamaah. Koperasi dilarang keras pinjam modal atau menerima bantuan dari pihak manapun, kecuali mendapat ijin dari pengasuh perjuangan yaitu KH. Abdul Latief Madjid. Pemupukan modal diupayakan dari modal sendiri, baik berupa simpanan pokok dan simpanan wajib maupun simpanan suka rela (tabungan jamaah). Karena itu, koperasi Wahidiyah diharapkan benar-benar mandiri, tidak tergantung dari pihak manapun.

Menyadari akan pentingnya membangun ekonomi bagi jamaahnya, maka Wahidiyah mewajibkan kepada seluruh jamaah yang sudah memenuhi syarat untuk menjadi anggota koperasi. Sosialisasi kepada jamaah yang belum sadar koperasi menjadi tanggung jawab pramu koperasi dan seluruh jajaran pramu departemen. Pramu adalah istilah yang digunakan oleh Wahidiyah untuk menyebut karyawan yang bekerja di lingkungannya. Sosialisasi sadar berkoperasi dilakukan melalui acara-acara resmi ke-Wahidiyah-an baik di tingkat kelompok/desa maupun di tingkat pusat seperti pada acara mujahadah kubro.

Selain bertanggung jawab untuk mensosialisasikan pentingnya berkoperasi, pramu koperasi dan pramu departemen Wahidiyah juga berkewajiban mengembangkan koperasi dan membina anggota koperasi. Mengembangkan koperasi dalam 
pengertian meningkatkan status koperasi dari koperasi simpan pinjam (awal berdiri) ke koperasi serba usaha. Sementara, membina anggota koperasi berarti mencarikan celah yang memungkinkan bagi anggota koperasi mendapatkan peluang kerja.

Tersebarnya jamaah Wahidiyah di seluruh pelosok Nusantara, memaksa koperasi ini dikelola dengan sistem yang rapi dan berjenjang. Karena itu, konsep yang dikembangkan untuk mengelolanya adalah klaster hirarkhi (kelompok berjenjang) yaitu mulai dari koperasi pusat yang ditangani oleh departemen koperasi pusat, dibawahnya departemen koperasi tingkat propinsi yang mengurus koperasi di tingkat propinsi, lalu departemen koperasi tingkat kabupaten/kota sampai dinas koperasi untuk tingkat kecamatan.

Perbedaannya dengan koperasi yang lain adalah pertama, setiap jamaah hanya diperbolehkan menjadi anggota pada satu koperasi di tempat domisilinya. Hal ini tujuannya di samping untuk mendata Pengamal Wahidiyah yang masuk menjadi anggota koperasi, juga untuk mencegah terjadinya kredit macet akibat perilaku yang tidak bertanggung jawab. Kedua, koperasi Wahidiyah hanya memberlakukan satu anggaran dasar. Karena itu, koperasi cabang harus menggunakan anggaran dasar yang sama dengan koperasi Wahidiyah pusat dan tidak diperbolehkan membuat anggaran dasar baru. Hal ini dimaksudkan agar koperasi cabang taat dengan peraturan-peraturan yang dibuat oleh koperasi pusat, dan tidak membuat aturan baru yang menyimpang dengan koperasi induknya. Ketiga, pengasuh Perjuangan Wahidiyah boleh melakukan intervensi terhadap koperasi yang menjadi cabangnya, walaupun yang bersangkutan bukan anggota koperasi tersebut. Hal ini dimaksudkan untuk mengantisipasi timbulnya penyimpangan atau usaha pemakaran yang mungkin dilakukan oleh koperasikoperasi yang menjadi cabangnya.

\section{Implementasi Pemberdayaan Ekonomidi Wabidiyah}

Pemberdayaan merupakan proses merubah perilaku seseorang menuju ke arah yang lebih baik dari kondisi sebelumnya. Merubah perilaku bukan sesuatu yang mudah, tetapi sesuatu yang cukup rumit, membutuhkan waktu panjang, dan tenaga yang handal dan 
profesional. Karena itu, pemberdayaan tidak dapat dilakukan secara asal-asalan. Pemberdayaan harus dilakukan dengan perencanaan yang matang, melalui proses yang jelas dan sistematis (Wrihatnolo, 2007), mulai dari penyadaran, capacity building dan pemberian daya.

Penyadaran merupakan pondasi bagi proses pemberdayaan. Tanpa kesadaran yang muncul dari masyarakat, pemberdayaan tidak memiliki arti sama sekali. Sebab, kesadaran masyarakat untuk merubah nasibnya sendiri merupakan kunci keberhasilan dari sebuah pemberdayaan. Hal ini menurut Kyai Zainuddin sudah dijelaskan dalam al-Qur'an surat al-Ra'du ayat 11 : "innallaba la yughayyiru ma bi-qaumin hatta yughayyiru ma bi-anfusibim (sesungguhnya Allah tidak merubah keadaan suatu kaum sehingga mereka merubah keadaan yang ada pada diri mereka sendiri)".

Sementara itu, KH. Abdul Latief Madjid menjelaskan bahwa penyadaran yang harus dilakukan pertama dalam pemberdayaan ekonomi adalah membangun mental spiritual. Hal ini penting, karena agama dapat menjadi alat kontrol bagi setiap orang dalam melakukan muamalah. Orang yang pengamalan agamanya baik, pasti kontrol dirinya baik, sebaliknya orang yang pengamalan agamanya jelek, kontrol dirinya juga jelek. Karena itu, pengamalan agama seseorang perlu dibangun dengan amalan-amalan yang mampu menggerakkan hati untuk selalu menjadi alat kontrol yang baik bagi dirinya. Di samping itu, menurut beliau bahwa pengamalan agama seseorang dapat menjadi daya dorong dalam meraih kesuksesan duniawi, khususnya yang berkaitan dengan masalah ekonomi. Lebih tegas beliau mengatakan sambil mensitir ayat 2-3 dari surat al-Thalaq dan ayat 186 dari surat alBaqarah bahwa kalau ada seorang muslim yang miskin perlu dipertanyakan iman orang tersebut.

Pembangunan mental spiritual jamaah Wahidiyah dilakukan melalui mujahadah. Pada pelaksanaannya, mujahadah ini terbagi menjadi dua, yaitu mujahadah individual dan kolektif. Mujahadah individual minimal dilaksanakan setiap selesai menjalankan sholat lima waktu baik dilakukan sendirian maupun 
berjamaah.Sementara, mujahadah kolektif dilaksanakan sesuai tingkat pelaksananya, seperti mujahadah usbu'iyah (mingguan) dilaksanakan di tingkat kelompok/desa, mujahadah syahriyah (bulanan) di tingkat kecamatan, mujahadah rubuiyah (tri wulan) di tingkat kabupaten, mujahadah nisfu sanah (semester) di tingkat propinsi dan mujahadah kubro di tingkat pusat (Kedunglo Kediri) yang dilakukan dua kali dalam setahun.Pada setiap mujahadah, materi yang dibaca adalah Sholawah Wahidiyah.

Setelah kesadaran mental spiritual terbentuk, proses berikutnya adalah membangun mental wirausaha. Usaha membangun mental wirausaha yang dilakukan oleh Wahidiyah untuk jamaahnya adalah melalui dua cara, yaitu secara resmi dan secara personal. Secara resmi dilakukan melalui acara-acara seremonial ke-Wahidiyah-an, seperti acara mujahadah, acara koperasi, wisuda sarjana dan sebagainya. Secara personal dilakukan melalui pengarahan dan bimbingan tokoh-tokoh Wahidiyah.

Sosialisasi "gerakan sadar berkoperasi" dilakukan agar jamaah Wahidiyah yang mayoritas berasal dari kalangan masyarakat miskin sadar bahwa cara membangun ekonomi yang kuat satu-satunya adalah melalui koperasi. Karena hanya dengan cara koperasi, paling tidak modal untuk memulai usaha mudah diperoleh bagi anggota. Di samping itu, sosialisasi ini dilakukan bukan hanya sekedar mensosialisasikan pentingnya menjadi anggota koperasi, tetapi sekaligus membangun kesadaran jamaah agar berkenan membuka peluang kerja baru. Misalnya melakukan sharing informasi mengenai peluang usaha yang dapat dilakukan bersama melalui wadah koperasi.

Sementara itu, usaha membangun kesadaran berwirausaha jamaah yang dilakukan secara personal banyak dilakukan oleh tokoh-tokoh Wahidiyah yang telah sukses membangun usahanya. Misalnya yang dilakukan oleh Heri Santoso. Setelah sukses mengembangkan usaha ternak ulat yang mendapat restu dari pengasuh Perjuangan Wahidiyah, beliau mengajak teman-temannya untuk mengembangkan usaha tersebut. Beliau membimbing dan melatihnya sendiri dan bahkan siap memasarkan hasil usaha dari teman-temannya tersebut. 
Setelah kesadaran spiritual dan kesadaran wirausaha tumbuh, proses berikutnya adalah capacity building. Capacitybuilding adalah upaya memberikan keahlian atau ketrampilan pada jamaah yang telah sadar untuk melakukan usaha/kerja agar mampu mengerjakan dengan sebaik-baiknya. Bentuk capacity building yang dilakukan meliputi dua macam yaitu individual dan kelembagaan. Capacity building individual dilakukan oleh pramu koperasi atau anggota koperasi kepada anggota lainnya, khususnya, anggota koperasi yang belum memiliki usaha agar dapat membuka usaha baru. Dengan kata lain, jamaah Wahidiyah yang memiliki ketrampilan usaha tertentu diharapkan dapat menularkan ketrampilannya tersebut kepada jamaah lainnya. Hal ini dimaksudkan agar seluruh jamaah Wahidiyah terbantu dalam upaya meningkatkan ekonominya sesuai dengan cita-cita yang telah digariskan pada Perjuangan Wahidiyah.

Praktik capacity building individual ini sudah banyak dilakukan oleh jamaah Wahidiyah. Misalnya pelatihan ternak ulat yang dilakukan oleh Heri Santoso seorang anggota koperasi Wahidiyah asal kota Blitar kepada anggota koperasi Wahidiyah lainnya yang ingin mengembangkan usaha tersebut. Pelatihan dilakukan dengan melihat langsung ternak ulat miliknya atau hanya sekedar melihat sampel sambil diberikan tehnik-tehnik melakukan dan merawatnya.

Pelatihan ketrampilan yang disampaikan oleh Heri Santoso ini tergolong pelatihan yang sederhana dan realistis. Karena prosesnya dilakukan dengan melihat langsung pada objek. Peserta pelatihan diajari cara-cara mengerjakan dan merawatnya sambil melihat objek secara langsung, sehingga mudah dimengerti dan dipahami oleh peserta pelatihan. Untuk itu, cukup beralasan kalau jamaah Wahidiyah yang mengikuti langkah Heri Santoso dalam mengembangkan ternak ini jumlahnya sudah mencapai (50) lima puluh orang lebih yang tersebar di Kabupaten Blitar dan Kediri. Hal itu, di samping, disebabkan oleh mudahnya cara beternak, juga karena pemasaran produk yang dihasilkan juga sudah jelas, yaitu dikoordinir oleh koperasi.

Sementara itu, capacity building kelembagaan dilakukan oleh pramu-pramu Wahidiyah untuk membangun dan 
mengembangkan koperasinya. Capacity building ini meliputi tiga bentuk yaitu manusia, organisasi dan sistem nilai. Capacity building manusia dimaksudkan untuk memberi atau melatih kemampuan individu atau kelompok agar dapat mengelola koperasi dengan baik dan benar. Kegiatannya dilakukan melalui pelatihan, workshop, seminar dan sejenisnya. Pelatihan-pelatihan semacam ini sering menggunakan metode ceramah, diskusi dan simulasi dari pada hanya sekedar ceramah dan diskusi saja. Hal ini dimaksudkan untuk mempermudah peserta pelatihan menerima, mengerti dan menguasai materi pelatihan.

Capacity building organisasi di antaranya dilakukan dalam bentuk restrukturisasi organisasi yang hendak menerima daya atau kapasitas tersebut. Misalnya, dalam kasus pelatihan kepengawasan koperasi di atas, kemudian Wahidiyah membentuk badan pengawas koperasi. Supaya manajemennya efisien, maka organisasi perkoperasian di Wahidiyah ditata ulang sehingga berpola strukture follow function. Dengan pola ini, Wahidiyah berharap dapat memperbaiki manajemen koperasinya setahap demi setahap, sehingga jika SDM telah memadahi dipastikan tidak akan terjadi kepengurusan tumpang tindih, seperti pengurus harian koperasi sekaligus menjadi pengawas koperasi yang mengakibatkan kontrol koperasi tidak berjalan.

Terakhir, capacity building sistem nilai dilaksanakan untuk mengatur kegiatan perkoperasian yang berjalan di Wahidiyah. Sistem nilai ini dibuat oleh pengasuh Perjuangan Wahidiyah untuk dijadikan pedoman dasar bagi pelaksanaan koperasi Wahidiyah, baik di tingkat pusat maupun daerah. Sistem nilai perkoperasian Wahidiyah bentuknya adalah buku panduan koperasi yang isinya meliputi anggaran dasar dan anggaran rumah tangga, sistem dan prosedur, peraturan koperasi, struktur organisasi dan sejenisnya.

Proses berikutnya setelah ketrampilan terbentuk adalah pemberian daya. Pemberian daya (empowerment dalam makna sempit) adalah upaya memberikan bantuan modal atau peluang usaha kepada jamaah yang hendak diberdayakan agar mampu mengelola usahanya secara mandiri. Dasar logikanya adalah 
bahwa penyadaran dan pemberian ketrampilan saja belum cukup tanpa dibarengi dengan bantuan modal atau peluang usaha agar dapat digunakan untuk mengawali menjalankan usaha.

Bentuk dan strategi pemberian daya dilakukan melalui dua jenis, yaitu bantuan pinjaman modal usaha dan bantuan pemasaran produk usaha. Kedua bantuan itu diberikan melalui koperasi. Bantuan pinjaman modal usaha diberikan kepada jamaah yang membutuhkan dengan jaminan (agunan) tertentu, misalnya dengan bukti pemilikan kendaraan bermotor (BPKB), sertifikat hak milik tanah, dan sejenisnya. Bagi koperasi yang kekurangan modal sehingga tidak dapat memberikan pinjaman kepada anggota dapat meminta bantuan pinjaman dari koperasi pusat melalui Badan Penyalur Bantuan Koperasi Wahidiyah (BPBKW) dengan syarat koperasi tersebut telah dinyatakan sehat oleh Badan Audit Keuangan Wahidiyah.

Sementara bantuan pemasaran produk usaha di antaranya dilakukan dengan pembuatan Griya Usaha Koperasi Wahidiyah (Griya UKW), seperti telah dirintis oleh Teguh Yuono di Kabupaten Malang. Griya UKW digunakan untuk menampung produksi yang dihasilkan oleh jamaah Wahidiyah karena yang bersangkutan belum dapat memasarkannya. Sebagaimana dituturkan oleh Teguh Yuono berikut ini "Saya bikin Griya UKW itu untuk mengakomodasi semua dari kreativitas pengamal Wahidiyah yang menjadi anggota koperasi dan tidak bisa memasarkan". Adapun strategi pemasaran yang digunakan dalam Griya UKW melalui tiga cara yaitu dengan sistem on line, kerja sama dengan koperasi-koperasi Wahidiyah di wilayah lain dan display di tempat.

Strategi lain dari bantuan pemasaran produk usaha adalah pemasaran bersama melalui koperasi. Selain dua strategi dalam membantu pemasaran produk usaha jamaah di atas, Wahidiyah juga mengadakan pameran produk-produk yang dihasilkan oleh anggota koperasi dari daerah-daerah. Pameran ini diadakan setahun sekali, yakni bersamaan dengan mujahadah kubro yang diselenggarakan pada bulan Rojab dan bertempat di Kedunglo Kediri. Karena itu, pameran ini sering disebut dengan Kedunglo 
Expo. Tujuan diadakan pameran adalah agar masing-masing koperasi saling mengetahui produk yang dihasilkan oleh koperasi lain. Harapannya adalah dengan saling mengetahui akan terjalin kerja sama khususnya dalam penjualan atau tukar menukar produk yang dihasilkan.

\section{Hasil Pemberdayaan Ekonomi di Wahidiyah}

Ada empat hal yang ditemukan dari hasil pemberdayaan ekonomi Wahidiyah terhadap jamaahnya, yaitu: terbentuknya wirausahawan yang jujur dan amanah yang dilandasi oleh pengamalan agama yang kuat, terwujudnya kemandirian atau kesejahteraan jamaah, terjaminnya keberlanjutan usaha karena banyaknya jaringan dengan jamaah lain, dan ketersediaan/ kemudahan akses modal untuk pengembangan usaha. Contoh kasus berikut ini setidaknyadapat memberikan ilustrasi terhadap simpulan di atas.

Sochibul Solchi seorang pramu koperasi Wahidiyah yang tinggal di Kecamatan Mojo Kabupaten Kediri. Selain aktif di koperasi, beliau juga menjalankan usaha pribadi yang berupa warung sembako. Awal mula memulai usaha karena didorong oleh rasa ingin membantu sesama jamaah. Menurutnya, waktu itu beliau melihat banyak jamaah Wahidiyah yang menjalankan usaha ternak ayam petelur dan sulit memasarkan karena harganya turun akibat permainan tengkulak. Kemudian beliau mempunyai inisiatif untuk menjual telur-telur tersebut ke pasar. Beliau pinjam modal dari koperasi sebesar Rp. 5.000.000,- (lima juta rupiah) dengan pertimbangan separuh dari dana tersebut digunakan untuk modal jalan dan separuhnya untuk modal cadangan.

Sochibul Solchi mengawali usaha dengan mencari pelanggan di pasar atau di warung rumahan dengan mengambil keuntungan kecil. Banyak pedagang pasar dan warung rumahan yang tertarik mengambil telur dari Sochib (panggilan akrab untuk Sochibul Solchi), karena mereka merasa harganya miring dibanding dengan tengkulak-tengkulak lainnya. Usaha itu terus berjalan dan terus meningkat seiring dengan berjalannya waktu, 
sehingga barang yang dijual tidak hanya telur, tetapi terus merambah ke bahan pokok lain, seperti beras, minyak, gula dan sebagainya. Demikian pula dengan tempat usahanya, saat ini beliau tidak hanya menjual barang dagangannya dengan cara droping, tetapi juga membuka usaha di rumah yang sehari-hari dikelola oleh istrinya.

Keberhasilan ini bagi Sochib tidak hanya disebabkan oleh ketekunannya dalam menjalankan usaha saja, tetapi juga karena ketaatannya dalam menjalankan ibadah. Pesan-pesan yang disampaikan oleh KH. Abdul Latief Madjid nampaknya membekas pada diri pribadi Sochib. Di antaranya adalah pesan bahwa do'a seseorang pasti diterima oleh Allah, jika orang tersebut berkenan mendekat dan meminta kepadaNya.

\section{Pembahasan Hasil Penelitian}

Wahidiyah membangun ekonomi jamaahnya melalui sebuah lembaga yang disebut koperasi. Koperasi yang secara terminologi mempunyai makna kerja sama menurut UU No. 25/1992 diartikan sebagai badan usaha yang beranggotakan orang per orang atau badan hukum koperasi yang melandaskan kegiatannya berdasarkan prinsip koperasi sekaligus sebagai gerakan ekonomi rakyat yang berdasar atas azas kekeluargaan. Pengertian ini mengandung batasan bahwa pertama, koperasi sebagai badan usaha harus memperoleh laba. Laba merupakan elemen kunci dalam suatu sistem usaha bisnis. Sistem usaha itu akan gagal bekerja tanpa memperoleh laba. Kedua, koperasi merupakan kumpulan orang per orang atau badan hukum. Ini berarti koperasi bukan kumpulan modal, melainkan kumpulan orang atau badan hukum. Bahkan secara tegas UU No. 25/1992 memberi batasan jumlah minimal orang atau badan hukum yang ingin membentuk organisasi koperasi, yaitu 20 orang untuk koperasi primer, dan 3 badan hukum koperasi untuk koperasi sekunder.

Ketiga, koperasi harus bekerja berdasar pada prinsipprinsipnya. Prinsip koperasi yang dimaksud adalah keanggotaan bersifat sukarela dan terbuka, pengelolaan dilakukan secara 
demokratis, pembagian sisa hasil usaha dilakukan secara adil sesuai dengan besarnya jasa usaha masing-masing anggota, pemberian batas jasa yang terbatas terhadap modal, kemandirian, pendidikan perkoperasian, dan kerja sama antar koperasi. Keempat, koperasi adalah gerakan ekonomi rakyat. Ini berarti koperasi merupakan bagian dari sistem perekonomian nasional. Karena itu, kegiatan usaha koperasi tidak semata-mata hanya ditujukan kepada anggota, tetapi juga kepada masyarakat umum. Kelima, koperasi berazaskan kekeluargaan. Keputusan yang berkaitan dengan usaha dan organisasi harus dilandasi dengan jiwa kekeluargaan. Segala keputusan yang diambil harus berdasarkan musyawarah dan mufakat.

Koperasi Wahidiyah yang berpusat di Kedunglo, Kalurahan Bandar Lor, Kecamatan Mojoroto, Kota Kediri ini telah berjalan sesuai dengan amanat UU No. 25/1992. Terbukti bahwa pertama, koperasi Wahidiyah sebagai sebuah badan usaha telah bekerja untuk memperoleh laba. Hal ini dapat dilihat baik pada koperasi simpan pinjam maupun koperasi serba usahanya. Pada koperasi simpan pinjam, misalnya, setiap peminjam di samping wajib membayar sejumlah pinjaman pokok, juga diwajibkan membayar jasa pinjaman sebesar tiga (3) persen dari jumlah pinjaman pokok. Jasa tiga persen ini merupakan laba yang diperoleh koperasi dari setiap melakukan transaksi peminjaman. Jasa ini menurut Kyai Abdul Latief Madjid adalah laba normal dan syah menurut ketentuan agama. Jasa ini tidak dapat digolongkan dalam pengertian riba seperti yang disinyalir dalam al-Qur'an Surat Ali Imran ayat 130. Karena, lebih lanjut Kyai Abdul Latief Madjid menjelaskan bahwa kategori riba dalam ayat tersebut ditunjukkan dengan lafadz "Adb'afan mudha'afatan" yang berarti lipat ganda yang tiada batasnya. Sementara, koperasi Wahidiyah telah membatasi dan menetapkan besaran jasanya, yaitu maksimal tiga (3) persen dari setiap transaksi peminjaman.

Pendapat Kyai Abdul Latief Madjid ini sejalan dengan pendapat Sjadzali (1997) meskipun argumentasi yang digunakan berbeda. Sjadzali menyatakan bahwa bunga atau jasa dari sebuah lembaga perbankan atau koperasi tidak haram. Karena, bank atau koperasi adalah suatu lembaga yang terhormat, dan sistem 
bunga atau jasa adalah satu mekanisme bank atau koperasi untuk mengelola modal masyarakat. Bank atau koperasi meminjamkan dana kepada masyarakat atau anggota yang membutuhkan modal usaha untuk jangka waktu tertentu. Peminjam akan mendapat keuntungan dari usahanya yang dimodali oleh bank atau koperasi itu. Sementara, pemilik dana akan kehilangan haknya untuk mempergunakan dananya untuk jangka waktu tertentu dengan menitipkan uang atau dananya kepada bank atau koperasi. Berdasarkan prinsip "tidak ada pihak yang dirugikan" seperti yang tertuang pada penghujung surat al-Baqarah ayat 279: la-tadblimun wa-la-tudblamun (kamu jangan merugikan dan kamu tidak dirugikan), maka tidak adil kalau pemilik dana yang kehilangan hak untuk mempergunakan dananya untuk jangka waktu tertentu tidak mendapat imbalan atau kompensasi dari pengorbanannya itu, sedangkan peminjam dana yang menggunakannya untuk modal usaha dan menjadi orang yang sukses atau beruntung tidak harus membagi keuntungannya dengan pemilik dana.

Bukti kedua koperasi Wahidiyah telah berjalan sesuai dengan amanat UU No. 25/1992 adalah bahwa koperasi Wahidiyah merupakan badan usaha yang beranggotakan orang per orang dari Pengamal Sholawat Wahidiyah maupun simpatisannya dengan melandaskan kegiatannya berdasar atas azas kekeluargaan dan ajaran Wahidiyah. Ini berarti koperasi Wahidiyah adalah koperasi primer. Karena, koperasi ini dibentuk oleh orang per orang dengan jumlah sekurang-kurangnya 20 (dua puluh) orang untuk melakukan kerja sama yang dilandasi oleh semangat kebersamaan dan kegotong-royongan. Nilai lebih yang dimiliki koperasi Wahidiyah di samping adanya sikap kebersamaan dan kegotong-royongan adalah adanya semangat yang ditumbuhkan dari ajaran Wahidiyah. Ajaran Wahidiyah yang meliputi lillāh-billāh, lirrasul-birrasul, lilghouts-bilghouts, yukti kulla dzi haqqin haqqob, dan taqdimul-ahamm falahamm tsummal-anfa' fal-anfa' dipastikan dapat mengontrol perilaku dari para pengurus dan anggotanya.

Bukti selanjutnya, koperasi Wahidiyah telah menerapkan prinsip-prinsip perkoperasian sebagaimana yang diamanatkan oleh UU No. 25/1992. Misalnya prinsip kemandirian. Koperasi 
Wahidiyah sangat menekankan pentingnya prinsip ini, bahkan begitu kuatnya berpegang terhadap prinsip ini, Pengasuh Yayasan Wahidiyah sampai melarang para pramu koperasi Wahidiyah baik di pusat maupun di daerah menerima bantuan dari pemerintah maupun swasta tanpa seijinnya. Kemandirian ini dimaknai oleh Wahidiyah sebagai lembaga yang dapat berdiri sendiri, dan tidak bergantung pada pihak lain.

Kondisi ekonomi jamaah yang rata-rata berada pada posisi kelas bawah menjadi faktor keberhasilan Wahidiyah dalam melakukan pemberdayaan ekonomi melalui koperasi. Jamaah yang memiliki berbagai keterbatasan tentu lebih mudah dipengaruhi dengan "janji-janji" manis yang dapat mengangkat kehidupan mereka menjadi lebih baik. Apalagi janji-janji itu disampaikan oleh tokoh atau idola mereka. Karena itu, strategi pemberdayaan dengan pendirian lembaga keuangan yang mudah diakses, seperti koperasi, menjadi angin segar bagi mereka. Kartasasmita (1995) telah mengingatkan bahwa untuk mencapai hasil yang diinginkan, maka strategi pemberdayaan ekonomi harus memihak kepada kelompok sasaran. Artinya program-program yang dirancang harus dapat mengatasi masalah dan sesuai dengan kebutuhan kelompok sasaran. Jamaah Wahidiyah yang rata-rata berada pada kelas bawah tentu sangat sulit mengakses modal di lembaga keuangan konvensional disebabkan ketiadaan agunan yang dimiliki. Karena itu, pendirian koperasi adalah cara tepat dan mudah untuk mengatasi permasalahan keuangan bagi jamaah Wahidiyah.

Pada proses pemberdayaan ekonomi, Wahidiyah memulai dengan membangun mental spiritual jamaah sebelum membangun mental wirausahanya. Ini artinya Wahidiyah membangun kesadaran yang paling dasar dalam membangun kesadaran jamaahnya untuk bekerja. Sebab, seseorang tidak akan bekerja dengan baik kalau etos kerjanya masih rendah. Dia akan sulit merubah kebiasaan bermalas-malasan, kalau kesadaran kerjanya tidak muncul dari dalam dirinya sendiri. Sebagaimana telah dijelaskan dalam al-Qur'an surat al-Ra'd ayat 11 yang menyatakan bahwa innallā hā la-yughoyyiru ma bi-qoumin hattā 
yughoyyiru ma bi-anfusibim (Sesungguhnya Allah tidak akan merubah keadaan sesuatu kaum, sehingga mereka merubah keadaan yang ada pada diri mereka sendiri). Karena itu, melalui siraman-siraman rohani dan pembiasaan mujahadah diharapkan tumbuh etos kerja dan kesadaran berwirausaha dalam diri para jamaah. Tasmara (2002) menyatakan bahwa bekerja merupakan fitroh manusia. Karena itu, orang yang enggan bekerja, malas, dan tidak berkenan mendayagunakan seluruh potensi dirinya untuk bekerja berarti dia melawan fitrohnya. Orang seperti itu perlu disadarkan dengan mengajarkan nilai-nilai agama pada dirinya. Sebab, setiap pribadi muslim pasti meyakini bahwa nilai iman, misalnya, akan terasa kelezatannya apabila secara nyata dimanifestasikan dalam bentuk amal saleh atau tindakan kreatif dan prestatif. Bekerja adalah salah satu bentuk tindakan kreatif dan prestatif. Sebab, dengan bekerja orang mampu menghasilkan sesuatu, dan dengan bekerja pula dia mampu menyumbangkan sebagian hasilnya untuk berbuat kebaikan.

Selanjutnya, setelah tumbuh kesadaran untuk berwirausaha, Wahidiyah memberikan capacity building bagi jamaahnya. Capacity building diberikan kepada individu maupun kelompok. Secara individu, capacity building dimaksudkan untuk membekali ketrampilan dan keahlian yang dibutuhkan untuk membuka usaha baru. Secara kelompok capacity building dimaksudkan untuk menata organisasi khususnya pada organisasi koperasi yang akan atau baru dibangun. Menurut Mardikanto (2010) pemberian capacity building seperti itu penting dalam rangka membina manusianya. Bahkan menurutnya capacity building bukan hanya pada manusia dan kelembagaan, tetapi juga pada jejaring. Ini artinya Wahidiyah perlu memberikan ketrampilan dan keahlian membangun jejaring kepada jamaahnya baik secara individu maupun kelompok.

Tahap terakhir yang dilakukan Wahidiyah dalam pemberdayaan ekonomi adalah pemberian daya. Wahidiyah telah menyiapkan bantuan daya tersebut untuk membangun atau mengembangkan usaha jamaahnya, yaitu dengan menyediakan bantuan modal usaha dan bantuan pemasaran produk usaha. Bantuan-bantuan tersebut terwadahi dalam satu lembaga yang 
disebut koperasi. Karena itu, bagi jamaah Wahidiyah yang telah menjadi anggota koperasi tentu dapat mengakses bantuan tersebut. Itulah fungsi koperasi bagi Wahidiyah, yaitu sebagai lembaga penyedia bantuan daya bagi jamaahnya pada proses pemberdayaan ekonomi. Penyediaan bantuan daya melalui sebuah lembaga yang mudah diakses ini dinilai tepat oleh Kartasasmita (1995). Pasalnya, masalah yang paling mendasar dalam rangka transformasi struktural, yaitu perubahan ekonomi tradisional ke modern, ekonomi lemah ke ekonomi kuat, ekonomi subsisten ke ekonomi pasar atau ketergantungan kepada kemandirian, adalah kemudahan akses ke dalam dana. Ketersediaan kredit yang mudah dan memadahi dapat menciptakan pembentukan modal bagi usaha masyarakat, sehingga dapat meningkatkan produksi dan pendapatan, serta menciptakan surplus yang dapat digunakan untuk membayar kembali kreditnya dan melakukan pemupukan modal. Karena itu, kemudahan akses ke dalam dana dipahami oleh Wahidiyah sebagai keterjangkauan pada saat diperlukan dan kemampuan untuk memanfaatkannya.

Proses pemberdayaan ekonomi yang dijalankan secara rapi oleh Wahidiyah dengan didukung input yang memadahi dapat menghasilkan keluaran yang baik. Munculnya wirausahawan baru seperti Sochibul Solchi merupakan contoh keluaran yang dihasilkan dari pemberdayaan ekonomi di Wahidiyah. Wahidiyah telah membangun kapasitas jamaah dan kelembagaannya, sehingga banyak bermunculan wirausahawan dan koperasi baru di berbagai daerah. Ini artinya Wahidiyah sebagai lembaga sosial keagamaan telah berpartisipasi dalam pembangunan bangsa khususnya dalam mengurangi angka kemiskinan. Karena itu, tidak berlebihan jika Mas'udi (2006) menyatakan bahwa umat Islam perlu kembali ke masjid. Karena masjid mampu menjawab problem ekonomi umat yang eskalasinya semakin meningkat pada saat ini. Umat Islam perlu membangun kembali lembaga keuangan Islam yang pernah ada pada masa lalu dan terlupakan pada saat ini. Terbukti dengan Wahidiyah membangun koperasi yang dilandasi nilai-nilai ajaran Islam mampu mengentaskan kemiskinan yang diderita oleh jamaahnya.

\section{Kesimpulan}


Wahidiyah membangun ekonomi jamaahnya melalui pengembangan koperasi. Konsep ini dipandang realistiskarena mayoritas jamaahnya berasal dari kalangan masyarakat ekonomi kelas bawah.Koperasi,bagi Wahidiyah, selain dijadikan sarana untuk membangun modal finansial, juga dijadikan wadah untuk membangun solidaritas antar anggota. Dengan solidaritas yang kuat dari para anggota, maka proses pemberdayaan ekonomi berjalan. Konsep berkoperasi yang dipahami dan diimplementasikan dengan baik oleh pengikut Wahidiyah berdampak positif terhadap hasil pemberdayaan ekonomi bagi jamaah Wahidiyah.Namun, keberhasilan pemberdayaan yang ditunjukkan dengan meningkatnya ekonomi bagi jamaah Wahidiyah bukan semata disebabkan oleh kejelasan konsep dan implementasi koperasi saja, tetapi juga disebabkan oleh etos kerja yang muncul dari pemahaman dan pengamalan agama yang diajarkan oleh Wahidiyah.

\section{Daftar Pustaka}


Abdullah, I. 1994. The Muslim Businessmen of Jatinom; Religious Reform and Economic Modernization in a Central Javanese Town. Disertasi. Amsterdam: Universitas Amsterdam.

Azra, A. 2004. Jaringan Ulama Timur Tengah dan Kepulauan Nusantara Abad XVII dan XVIII: Akar Pembaruan Islam Indonesia. Jakarta: Kencana.

Chotimah, C. 2014. Pendidikan Kewirausahaan di Pondok Pesantren Sidogiri Pasuruan. Inferensi: Jurnal Penelitian Sosial Keagamaan. Vol. 8 No. 1: 115-136.

Fauroni, R. L. 2011. Model Pemberdayaan Ekonomi Ala Pesantren AlIttifaq Rancangbali Kab. Bandung. Inferensi: Jurnal Penelitian Sosial Keagamaan. Vol. 5 No. 1: 1-17.

Gemari. 2007. Menag Canagkan Posdaya Berbasis Masjid di Pemalang. Edisi 74 Tahun VIII. Maret 2007. 58-59.

Kartasasmita, G. 1995. Pemberdayaan Masyarakat. Bahan Kuliah Program Pascasarjana Program Studi Pembangunan. Bandung: ITB.

Mardikanto, T. 2010a. Konsep-Konsep Pemberdayaan Masyarakat: Acuan Bagi Aparat Birokrasi, Akademisi, Praktisi dan Peminat/ Pemerhati Pemberdayaan Masyarakat. Surakarta: Fakultas Pertanian UNS.

Mas'udi, M.F. 2006. Memakmurkan Masjid Nahdliyin untuk Kejayaan Umat dan Bangsa. Jakarta: P3M.

Muslim, A. 2014,Model Pemberdayaan Ekonomi Masyarakat Miskin Perkotaan Berbasis Tanggung Jawab Sosial Masjid,Disertasi, Surakarta: Program Doktor Penyuluhan Pembangunan/ Pemberdayaan Masyarakat UNS. 
Muttaqin, R. 2011. Kemandirian dan Pemberdayaan Ekonomi Berbasis Pesantren. Jurnal Ekonomi Syariah Islam. Vol. 1 No. 2: 65-94.

Oepen, M. dan Karcher, W. 1988. Dinamika Pesantren. Jakarta: P3M. Sjadzali, M. 1997. Ijtihad Kemanusiaan. Jakarta: Paramadina.

Sobary, M. 1995. Kesalehan dan Tingkah Laku Ekonomi. Yogyakarta: Bentang.

Tasmara, T. 2002. Membudayakan Etos Kerja Islami. Jakarta: Gema Insani.

Wrihatnolo, R.R. dan Dwidjowijoto, R.N. 2007. Manajemen Pemberdayaan: Sebuah Pengantar dan Panduan untuk Pemberdayaan Masyarakat. Jakarta: PT Elex Media Komputindo. 